\title{
FAKTOR RISIKO YANG BERHUBUNGAN DENGAN KEJADIAN PENYAKIT REMATIK DI WILAYAH KERJA PUSKESMAS WUNA KECAMATAN BARANGKA KABUPATEN MUNA BARAT TAHUN 2019
}

\author{
Siti Sulafati ${ }^{1}$ Yasnani ${ }^{2}$ Renni Meliahsari ${ }^{3}$ \\ 1,2,3 Fakultas Kesehatan Masyarakat Universitas Halu Oleo \\ ${ }^{1}$ sitisulafatisamarandi97@gmail.com ${ }^{2}$ yasnani rahabuddin@yahoo.com ${ }^{3}$ renni.meliahsari@gmail.com
}

\begin{abstract}
Abstrak
Rematik merupakan kelompok penyakit heterogen sebagai akibat deposisi kristal monosodium urat (MSU) pada jaringan atau akibat supersaturasi asam urat di dalam cairan ekstraseluler merupakan pemicu utama terjadinya peradangan atau inflamasi kejadian rematik. Penyakit rematik ini merupakan salah satu penyakit yang sering ditemukan dan tersebar di seluruh dunia. Data Puskesmas Wuna menunjukkan jumlah kasus penyakit rematiki tergolong cukup tinggi. Pada tahun 2016 yaitu 364 kasus (30,46\%), tahun 2017 yaitu 382 kasus (31,97\%), dan pada tahun 2018 sebanyak 449 kasus (37,57\%). Tujuan penelitian ini adalah untuk mengetahui faktor risiko yang berhubungan dengan kejadian penyakit rematik di wilayah kerja Puskesmas Wuna Kecamatan Barangka Kabupaten Muna Barat Tahun 2019. Metode penelitian yang digunakan adalah metode penelitian kuantitatif dengan rancangan case control study. Populasi adalah semua pasien rematik tercatat pada rekam medik di Puskesmas Wuna selama Bulan Mei hingga Oktober tahun 2019 sebanyak 204 pasien dengan jumlah sampel sebanyak 116 responden terdiri dari 58 sebagai sampel kasus dan 58 sebagai sampel kontrol yang diperoleh menggunakan teknik proportional random sampling. Data dianalisis secara univariat dan bivariat dengan menggunakan uji Chi-square. Hasil penelitian menunjukkan ada hubungan antara aktivitas fisik $(p=0,000$ dan nilai $\mathrm{OR}=5.884)$ dengan kejadian penyakit rematik. Tidak terdapat hubungan antara asupan purin ( $p=0.155$ dan $\mathrm{OR}=1.989$.) dan IMT ( $p=0.565$ dan $\mathrm{OR}=0.820$ ) dengan kejadian penyakit rematik.
\end{abstract}

Kata Kunci : Penyakit Rematik, Asupan Purin, Aktivitas Fisik, IMT.

\begin{abstract}
Rheumatism is a heterogeneous group of diseases as a result of deposition of monosodium urate crystals (MSU) in tissues or due to supersaturation of uric acid in extracellular fluid is the main trigger for inflammation or inflammation of rheumatic events. This rheumatic disease is a disease that is often found and spread throughout the world. Data from the Wuna Health Center shows that the number of cases of rheumatoid disease is quite high. In 2016 there were 364 cases (30.46\%), in 2017 there were 382 cases (31.97\%), and in 2018 there were 449 cases (37.57\%). The purpose of this study was to determine the risk factors associated with the incidence of rheumatic diseases in the working area of Wuna Health Center, Barangka District, West Muna Barat regency in 2019. The research method used was a quantitative research method with a case control study design. The population was all rheumatic patients recorded in the medical records at the Wuna Health Center during May to October 2019 as many as 204 patients with a total sample of 116 respondents consisting of 58 as case samples and 58 as control samples obtained using proportional random sampling techniques. Data were analyzed univariately and bivariately using the Chi-square test. The results showed there was a relationship between physical activity $(p=0,000$ and OR value $=5,884)$ with the incidence of rheumatic disease. There was no relationship between purine intake ( $p=0.155$ and $O R=1,989)$ and BMI $(p=0.565$ and $O R=0.820$ ) with the incidence of rheumatic disease.
\end{abstract}

Keywords : Rheumatic Disease, Purine Intake, Physical Activity, BMI 


\section{PENDAHULUAN}

Nyeri sendi sering disebut dengan rematik adalah penyakit yang sering ditemukan dan tersebar di seluruh dunia. Rematik merupakan kelompok penyakit heterogen sebagai akibat deposisi kristal monosodium urat (MSU) pada jaringan atau akibat supersaturasi asam urat di dalam cairan ekstraseluler merupakan pemicu utama terjadinya peradangan atau inflamasi kejadian rematik. Gangguan metabolisme yang mendasarkan rematik adalah hiperurisemia yang didefinisikan sebagai peninggian kadar urat lebih dari $7,0 \mathrm{ml} / \mathrm{dl}$ untuk pria dan $6,0 \mathrm{ml} / \mathrm{dl}$ untuk wanita, kejadian ini meningkat pada lanjut usia ${ }^{1}$.

Di dunia, rematik merupakan penyakit muskuloskeletal yang paling sering terjadi. Angka kejadian rematik pada tahun 2013 yang dilaporkan oleh World Health Organization (WHO) adalah mencapai $20 \%$ dari penduduk dunia yang telah terserang rematik, dimana $5-10 \%$ adalah mereka yang berusia 5-20 tahun dan 20\% adalah mereka yang berusia 55 tahun $^{2}$.

Provinsi Sulawesi Tenggara pada tahun 2016 melalui Dinas Kesehatan menyebutkan bahwa penyakit pada sistem otot (rematik) menempati urutan ke-4 dari 10 penyakit terbanyak yang dilaporkan dari keseluruhan Puskesmas. Data ini menunjukkan prevalensi penyakit rematik sebanyak $22,5 \%{ }^{3}$.

Penyakit rematik merupakan salah satu dari 10 besar kasus penyakit tidak menular yang ada di Kabupaten Muna Barat. Berdasarkan data yang diperoleh dari profil Dinas Kesehatan Kabupaten Muna Barat pada tahun 2016 terdapat 3357 kasus ${ }^{4}$. Puskesmas Wuna termasuk salah satu dari 15 puskesmas di Kabupaten Muna Barat dengan kunjungan rematik yang cukup banyak di Kabupaten Muna Barat. Selama tiga tahun terakhir, penyakit rematik masuk dalam urutan sepuluh besar penyakit yang ada di Puskesmas Wuna. Data yang diperoleh dari Profil Puskesmas Wuna yaitu pada tahun 2016 penyakit rematik menduduki urutan kedua dengan jumlah penderita rematik sebanyak 364 kasus, tahun 2017 penyakit rematik masih berada pada urutan kedua dengan jumlah penderita sebanyak 382 kasus, dan pada tahun 2018 penyakit rematik menduduki urutan pertama dengan jumlah penderita sebanyak 449 kasus. Berdasarkan data tersebut dapat disimpulkan bahwa dari tahun 2016 sampai dengan tahun 2018 penyakit rematik mengalami peningkatan sehingga masih menjadi masalah kesehatan di Puskesmas Wuna ${ }^{5}$.

Rematik merupakan penyakit yang serangannya sangat di pengaruhi oleh asupan purin. Mengkomsumsi makanan yang banyak mengandung purin dapat menyebabkan terjadinya pengkristalisasian dalam sendi. Agar terhindar dari rematik salah satu caranya adalah menjaga makanan yang mengandung purin dalam darah dalam posisi normal yaitu $5-7 \mathrm{mmg} \%^{6}$.

Aktivitas yang berat dapat memperberat penyakit rematik atau yang ditandai dengan peningkatan kadar asam urat dalam darah. Olahraga atau gerakan fisik akan menyebabkan peningkatan kadar asam laktat. Meningkatnya kadar asam laktat dalam darah menyebabkan pengeluaran asam urat mengalami penurunan sehingga kandungan asam urat dalam tubuh meningkat. Aktivitas fisik atau olahraga secara teratur bermanfaat untuk mengatur berat badan serta menguatkan sistem jantung dan pembuluh darah. Proporsi aktivitas fisik penduduk di Indonesia tergolong kurang aktif, secara umum yang melakukan aktivitas fisik aktif sebesar 33,5\% saja. Sedangkan proporsi penduduk yang melakukan aktivitas fisik cukup sebesar 66,5\%. Berdasarkan kelompok umur terdapat kecenderungan semakin bertambah umur semakin menurun proporsi perilaku aktivitas fisik ${ }^{7}$.

Faktor risiko lain yang menyebabkan penyakit rematik adalah status gizi. Obesitas merupakan penilaian status gizi seseorang apabila di atas ambang batas normal. Rematik pada obesitas terjadi melalui resistensi hormon insulin. Tubuh yang mengalami obesitas akan terjadi peningkatan pelepasan jumlah asam lemak bebas ke dalam sirkulasi. Masuknya asam lemak bebas yang berlebihan ini ke dalam otot mengakibatkan terjadinya resistensi insulin. Resistensi insulin, hipoksia, dan kematian sel dapat menginduksi perubahan Xhantine dengan bantuan air dan oksigen akan berubah menjadi asam urat yang menghasilkan peroksida. Selain itu, insulin juga berperan dalam meningkatkan reabsorbsi asam urat di tubuli proksimal ginjal yang dapat menyebabkan rematik ${ }^{8}$.

Berdasarkan uraian latar belakang dan permasalahan tersebut dilakukan penelitian dengan judul Faktor Risiko yang Berhubungan dengan Kejadian Penyakit Rematik di Wilayah Kerja Puskesmas Wuna Kecamatan Barangka Kabupaten Muna Barat Tahun 2019.

\section{METODE}

Metode penelitian yang digunakan adalah metode penelitian kuantitatif dengan rancangan case control study. Adapun tujuan penelitian ini adalah untuk mengetahui faktor risiko yang berhubungan dengan kejadian penyakit rematik di wilayah kerja Puskesmas Wuna Kecamatan Barangka Kabupaten Muna Barat Tahun 2019.

Populasi adalah semua pasien rematik tercatat pada rekam medik di Puskesmas Wuna 
selama Bulan Mei hingga Oktober tahun 2019 sebanyak 204 pasien dengan jumlah sampel sebanyak 116 responden terdiri dari 58 sebagai sampel kasus dan 58 sebagai sampel kontrol yang diperoleh menggunakan teknik proportional random sampling.

Adapun variabel dalam penelitian ini yaitu Variabel bebas adalah asupan purin, aktivitas fisik dan Indeks Massa Tubuh (IMT). Variabel terikat kejadian penyakit rematik. Instrumen yang digunakan dalam penelitian ini yaitu Kueisioner atau daftar pertanyaan tentang variabel-variabel yang diteliti, alat tulis, terdiri dari buku tulis, kertas dan pulpen, timbangan yaitu alat untuk mengukur berat badan, microtoise yaitu alat untuk mengukur tinggi badan, kalkulator yaitu alat yang digunakan untuk mengolah data yang diperoleh, komputer yaitu alat yang digunakan untuk menyusun laporan hasil penelitian dengan memakai perangkat lunak analisa data dan formulir persetujuan menjadi responden

Analisis data dalam penelitian ini terdiri dari dua analisis, pertama analisis univariat di lakukan untuk mendapatkan gambaran umum variabel yang di teliti dilakukan dengan mendeskripsikan masingmasing variabel dengan analisis dan distribusi frekuensi dan kedua analisis bivariat digunakan untuk mengetehui ada atau tidaknya hubungan asupan purin, aktivitas fisik dan IMT, dalam analisis ini dilakukan dengan pengujian statistik yaitu dengan uji chi-square pada taraf kepercayaan 95\%.

HASIL

Tabel 1. Hubungan Asupan Purin dengan Kejadian Penyakit Rematik di Wilyah Kerja Puskesmas Wuna Kecamatan Barangka Kabupaten Muna Barat Tahun 2019

\begin{tabular}{|c|c|c|c|c|c|c|c|c|c|}
\hline \multirow{3}{*}{ Asupan Purin } & \multicolumn{4}{|c|}{ Penyakit Rematik } & \multirow{2}{*}{\multicolumn{2}{|c|}{ Total }} & \multirow{3}{*}{ OR } & \multirow{2}{*}{\multicolumn{2}{|c|}{$95 \% \mathrm{Cl}$}} \\
\hline & \multicolumn{2}{|c|}{ Kasus } & \multicolumn{2}{|c|}{ Kontrol } & & & & & \\
\hline & $n$ & $\%$ & $n$ & $\%$ & $n$ & $\%$ & & Lower & Upper \\
\hline Normal & 44 & 38 & 50 & 43 & 94 & 81 & \multirow{3}{*}{$\begin{array}{l}\text { の } \\
\text { ద్ } \\
\text { - }\end{array}$} & \multirow{3}{*}{0.763} & \multirow{3}{*}{5.186} \\
\hline Lebih & 14 & 7 & 8 & 12 & 22 & 19 & & & \\
\hline Total & & 50.0 & 58 & 50.0 & 116 & 100 & & & \\
\hline
\end{tabular}

Sumber : Data Primer, November 2019

Tabel 2. Hubungan Aktivitas Fisik dengan Kejadian Penyakit Rematik di Wilyah Kerja Puskesmas Wuna Kecamatan Barangka Kabupaten Muna Barat Tahun 2019

\begin{tabular}{|c|c|c|c|c|c|c|c|c|c|}
\hline \multirow{3}{*}{ Aktivitas Fisik } & \multicolumn{4}{|c|}{ Penyakit Rematik } & \multirow{2}{*}{\multicolumn{2}{|c|}{ Total }} & \multirow{3}{*}{ OR } & \multirow{2}{*}{\multicolumn{2}{|c|}{$95 \% \mathrm{Cl}$}} \\
\hline & \multicolumn{2}{|c|}{ Kasus } & \multicolumn{2}{|c|}{ Kontrol } & & & & & \\
\hline & $n$ & $\%$ & $n$ & $\%$ & $N$ & $\%$ & & Lower & Upper \\
\hline Ringan-Sedang & 15 & 12.9 & 39 & 33.7 & 54 & 46.6 & \multirow{3}{*}{$\begin{array}{l}\forall \\
\infty \\
\infty \\
\dot{1}\end{array}$} & \multirow{3}{*}{2.632} & \multirow{3}{*}{13.146} \\
\hline Berat & 43 & 37.0 & 19 & 16.4 & 62 & 53.4 & & & \\
\hline Total & 58 & 50.0 & 58 & 50.0 & 116 & 100 & & & \\
\hline
\end{tabular}

Sumber : Data Primer, November 2019.

Tabel 3 Hubungan IMT dengan Kejadian Penyakit Rematik di Wilyah Kerja Puskesmas Wuna Kecamatan Barangka Kabupaten Muna Barat Tahun 2019

\begin{tabular}{|c|c|c|c|c|c|c|c|c|c|}
\hline \multirow{3}{*}{ IMT } & \multicolumn{4}{|c|}{ Penyakit Rematik } & \multirow{2}{*}{\multicolumn{2}{|c|}{ Total }} & \multirow{3}{*}{ OR } & \multirow{2}{*}{\multicolumn{2}{|c|}{$95 \% \mathrm{Cl}$}} \\
\hline & \multicolumn{2}{|c|}{ Kasus } & \multicolumn{2}{|c|}{ Kontrol } & & & & & \\
\hline & $n$ & $\%$ & $n$ & $\%$ & $n$ & $\%$ & & Lower & Upper \\
\hline Berisiko & 14 & 12.0 & 12 & 10.4 & 26 & 22.4 & \multirow{3}{*}{ 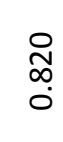 } & \multirow{3}{*}{0.342} & \multirow{3}{*}{1.966} \\
\hline Tidak Berisiko & 44 & 37.9 & 46 & 39.7 & 90 & 77.6 & & & \\
\hline Total & 58 & 50.0 & 58 & 50.0 & 116 & 100 & & & \\
\hline
\end{tabular}

Sumber : Data Primer, November 2019.

DISKUSI

Hubungan Asupan Purin dengan Kejadian Penyakit Rematik di Wilayah Kerjam Puskesmas Wuna Kecamatan Barangka Kabupaten Muna Barat Tahun 2019.
Purin merupakan satu senyawa di metabolisme di dalam tubuh dan menghasilkan produk akhir yaitu asam urat. Jenis makanan Kandungan purin dengan kategori rendah merupakan jenis makanan yang dapat dimakan setiap hari, yaitu berupa nasi, ubi, singkong, jagung, 
roti, mie, bihun, tepung beras, cake, kue kering, pudding, susu, keju, telur, lemak dan minyak, gula, sayuran, dan buah-buahan. Berdasakan hasil temuan dan teori tersebut di atas, maka konsumsi asupan makanan yang rendah purin merupakan jenis makanan yang aman dikonsumsi bagi masyarakat yang sedang melakukan diet purin. Makanan yang aman di sini adalah jenis makanan yang dikonsumsi oleh setiap orang dan pada setiap harinya atau dapat dikatakan bahwa jenis makanan rendah purin adalah jenis makanan pokok yang dionsumsi setiap hari ${ }^{9}$. Seseorang yang mengalami penyakit rematik dapat disebabkan oleh beberapa faktor, salah satunya adalah makanan yang dikonsumsi umumnya makanan yang tidak seimbang (asupan protein yang mengandung purin terlalu tinggi $)^{10}$.

Berdasarkan hasil penelitian di wilayah kerja Puskesmas Wuna Kecamatan Barangka Kabupaten Muna Barat menunjukan bahwa responden dengan asupan purin normal pada kelompok kasus yaitu sebanyak 44 orang (38\%) dan responden dengan asupan purin lebih sebanyak 8 orang (7\%). Sedangkan pada kelompok kontrol responden dengan asupan purin normal sebanyak 50 orang (43\%) dan responden dengan asupan purin lebih sebanyak 14 orang (12\%).

Hasil uji statistik Chi-Square menunjukkan bahwa tidak ada hubungan yang bermakna antara asupan purin dengan kejadian penyakit rematik di wilayah kerja Puskesmas Wuna Kecamatan Barangka Kabupaten Muna Barat Tahun 2019 dimana Odds Ratio $(O R)=1.989$. Mengkonsumsi makanan yang mengandung tinggi purin memang dapat menyebabkan terjadinya penyakit rematik. Namun dalam penelitian ini tidak terdapat hubungan yang signifikan antara asupan purin dengan kejadian penyakit rematik di wilayah kerja Puskesmas Wuna karena berdasarkan keadaan dilapangan pada saat peneliti melakukan food recall sebagian besar responden mengkonsumsi asupan makanan yang mengandung purin masih tergolong rendah. Peneliti berasumsi bahwa hal ini disebabkan karena wilayah kerja Puskesmas Wuna merupakan daerah pedesaan dengan variasi makanan penduduk yang relatif lebih sedikit jika dibandingkan dengan penduduk di daerah perkotaan.

Hasil penelitian ini sejalan dengan penelitian yang dilakukan oleh Andry et al (2009) bahwa tidak ada hubungan antara asupan purin dengan kadar asam urat ${ }^{11}$. Penelitian ini tidak sejalan dengan penelitian Khoirina (2016) bahwa ada hubungan antara asupan purin dengan kejadian terduga rematik pada pralansia di pos pembinaan terpadu (posbindu) wilayah kerja puskesmas pamulang tahun. Penelitian ini berbeda karena menggunakan jenis penelitian epidemiologi observasional analitik dengan desain studi cross sectional yang dilakukan untuk mengetahui hubungan antara variabel dependen dan variabel independen, dan teknik probability sampling dengan proportionate random sampling. Hal ini yang menyebabkan perbedaan hasil penelitian dan didapatkan jumlah sampel sebanyak 93 orang ${ }^{12}$.

\section{Hubungan Aktivitas Fisik dengan Kejadian Penyakit Rematik di Wilayah Kerjam Puskesmas Wuna Kecamatan Barangka Kabupaten Muna Barat Tahun 2019.}

Pekerjaan/aktivitas merupakan salah satu faktor munculnya penyakit rematik. Berbagai aktivitas dengan beban pekerja dan daya tekanannya yang dapat memperberat sendi dan pekerjaan yang banyak menggunakan tangan dalam jangka waktu yang lama, sering yang menjadi keluhan-keluhan yang dapat dirasakan pada setiap penderita penyakit rematik ${ }^{13}$

Beberapa pendapat menyampaikan bahwa olahraga atau aktivitas fisik yang berlebihan akan menyebabkan peningkatan asam laktat. Asam laktat tersebut akan menghambat dan menurunkan pengeluaran asam urat. Namun, ketika kenaikan asam laktat tersebut hanya berlangsung sebentar saja, maka kadar asam urat akan kembali normal dalam beberapa jam kemudian ${ }^{14}$.

Berdasarkan hasil penelitian yang dilakukan di wilayah kerja Puskesmas Wuna Kecamatan Barangka Kabupaten Muna Barat menunjukan bahwa responden dengan aktivitas fisik kategori ringan-sedang pada kelompok kasus yaitu sebanyak 15 oang (12.9\%) dan responden dengan aktivitas fisik kategori berat sebanyak 43 orang (37.0\%). Sedangkan pada kelompok kontrol responden dengan aktivitas fisik kategori ringan-sedang sebanyak 39 orang (33.7\%) dan responden dengan aktivitas fisik kategori berat sebanyak 19 orang (16.4\%).

Hasil uji statistik Chi-Square menunjukkan bahwa ada hubungan yang bermakna antara aktivitas fisik dengan kejadian penyakit rematik di wilayah kerja Puskesmas Wuna Kecamatan Barangka Kabupaten Muna Barat Tahun 2019 dimana nilai Odds Ratio $(\mathrm{OR})=5.884$. Peneliti berasumsi bahwa adanya hubungan antara faktor aktivitas fisik dengan penyakit rematik di wilayah kerja Puskesmas Wuna disebabkan karena sebagian besar responden bekerja sebagai petani yang menghabiskan waktunya pada siang hari untuk melakukan aktivitas fisik kategori berat yakni mencangkul, sering mengangkat beban berat, membuat pagar dan sebagainya. Dari hasil penelitian diketahui bahwa responden mengatakan sering mengalami sakit dibagian pinggang, pergelangan tangan dan lutut. Hasil penelitian ini sejalan dengan penelitian yang dilakukan oleh Ahdaniar, et al (2013) dengan judul 
penelitian Faktor yang Berhubungan dengan Kejadian Penyakit Rematik Pada Lansia di Wilayah Puskesmas Kassi-Kassi Kota Makassar, dimana hasil penelitian menunjukkan bahwa ada hubungan aktivitas fisik dengan kejadian penyakit rematik pada lansia didaptkan nilai $p=0,021 \quad(p<0,005)^{15}$. Penelitian lain yang dilakukan oleh Pursriningsih dan Panunggal (2015) di SMA Negeri 2 Slawi disimpulkan bahwa terdapat hubungan antara aktivi tas fisik terhadap kadar asam urat pada remaja lakilaki $(\rho \text { Value }=0,000)^{16}$. Tetapi Penelitian ini tidak sejalan dengan penelitian Andry (2009) yang menyatakan bahwa tidak ada hubungan aktivitas fisik dengan kejadian rematik didaptkan nilai $p=$ $0,908(p>0,005)^{17}$.

Hubungan IMTdengan Kejadian Penyakit Rematik di Wilayah Kerjam Puskesmas Wuna Kecamatan Barangka Kabupaten Muna Barat Tahun 2019.

Obesitas/overweight (IMT $\geq 22,9$ ) merupakan salah satu faktor risiko terjadinya rematik. Obesitas/overweight didefinisikan sebagai kondisi dimana terjadi kelebihan lemak tubuh. Pada orang Obesitas/overweight terjadi peningkatan asam urat terutama karena adanya peningkatan lemak tubuh, selain itu juga berhubungan dengan luas permukaan tubuh sehingga pada orang gemuk akan lebih banyak memproduksi urat dari pada orang kurus ${ }^{18}$.

Berdasarkan hasil penelitian yang dilakukan di wilayah kerja Puskesmas Wuna Kecamatan Barangka Kabupaten Muna Barat menunjukan bahwa responden dengan IMT kategori berisiko pada kelompok kasus yaitu sebanyak 14 orang (12.0\%) dan responden dengan IMT kategori tidak berisiko sebanyak 44 orang (37.9\%). Sedangkan pada kelompok kontrol responden dengan IMT kategori berisiko sebanyak 12 orang (10.4\%) dan responden dengan IMT kategori tidak berisiko sebanyak 46 orang (39.7\%).

Hasil uji statistik Chi-Square menunjukkan bahwa tidak ada hubungan yang bermakna antara IMT dengan kejadian penyakit rematik di wilayah kerja Puskesmas Wuna Kecamatan Barangka Kabupaten Muna Barat Tahun 2019 dimana Odds Ratio $(O R)=0.342$.

Hasil penelitian ini sejalan dengan penelitian yang dilakukan di Kota Semarang, oleh Koentjoro (2010) yang menjelaskan bahwa tidak terdapat hubungan yang bermakna antara Indeks Massa Tubuh dengan derajad osteoartritis yang merupakan penyebab rematik $(\rho \text { Value }=1,000)^{19}$. Penelitian lain yang dilakukan oleh Fuzan (2016) bahwa tidak terdapat hubungan antara IMT kurus dengan kejadian gout arthritis $(p=0.363)^{20}$. Tetapi penelitian ini tidak sejalan dengan penelitian yang dilakukan oleh Meliny, et al, (2017), yang menjelaskan bahwa ada hubungan antara IMT dengan penyakit rematik ( $\rho$ Value $=0,000)$. Penelitian ini berbeda karena menggunakan jenis deskriptif analitik dengan desain cross sectional study. yang dilakukan untuk mengetahui hubungan antara variabel dependen dan variabel independen, dan teknik total sampling. Hal ini yang menyebabkan perbedaan hasil penelitian dan didapatkan jumlah sampel sebanyak 91 orang $^{21}$.

IMT yang kurang baik tak hanya berkaitan dengan rematik pada sendi yang menanggung beban, tapi juga dengan rematik sendi lain (tangan). Demikian pula dengan menjelaskan bahwa orang yang memiliki nilai IMT lebih dari 22,9 memiliki risiko untuk menderita penyakit radang sendi² 2 .

Urin yang memliki $\mathrm{pH}$ sangat asam dapat mengakibatkan pengendapan dalam konsentrasi yang tinggi membentuk sodium urate. Tingginya konsentrasi tersebut dapat meningkatkan kadar asam urat dalam tubuh seseorang. Tingkat asam urat dalam serum yang tinggi atau hiperurisemia dapat mengakibatkan penyakit gout, sehingga peningkatan kadar leptin seiring dengan meningkatnya kadar asam urat dalam darah. Hal tersebut dikarenakan adanya gangguan proses reabsorpsi asam urat pada ginjal ${ }^{23}$.

Kegemukan sebagai akibat gangguan keseimbangan zat gizi dapat dilihat dari indikator berat badan normal, yaitu berat badan yang sesuai untuk tinggi badannya. Oleh karena itu, sangat dianjurkan untuk memantau berat badan normal setiap melakukan kunjungan ke puskesmas, sehingga dapat mencegah penyimpangan berat badan dan melakukan penanganannya.

\section{SIMPULAN}

1. Tidak ada hubungan yang bermakna antara asupan purin dengan kejadian penyakit rematik di Wilayah Kerja Puskesmas Wuna Kecamatan Barangka Kabupaten Muna Barat Tahun 2019 dengan nilai $p=0.155$ dan $\mathrm{OR}=1.989$.

2. Ada hubungan yang bermakna antara aktivitas fisik dengan kejadian penyakit rematik di wilayah kerja puskesmas wuna kecamatan barangka kabupaten muna barat tahun 2019 dengan nilai $p=0,000$ dan nilai $O R=5.884$ artinya bahwa orang dengan aktivitas fisik berat memiliki peluang risiko 5.884 kali lebih besar penyakit rematik dibandingkan dengan orang yang dengan aktivitas fisik kategori ringan-sedang.

3. Tidak hubungan yang bermakna antara IMT dengan kejadian penyakit rematik di Wilayah Kerja Puskesmas Wuna Kecamatan Barangka Kabupaten Muna Barat Tahun 2019 dengan nilai $p=0.565$ dan $\mathrm{OR}=0.820$.

\section{DAFTAR PUSTAKA}


1. Handayani, T. L. 2017. Faktor Dominan Peningkatan Kadar Asam Urat Pada Arhtritis di Wilayah Kerja Puskesmas di Kabupaten Jember. JRKN, 1(2), 95-101.

2. Word Health Organization (WHO) tahun 2013

3. Dinas Kesehatan Provinsi Sulawesi Tenggara, 2016. Profil Kesehatan Provinsi Sulawesi Tenggara. Kendari: Dinas Kesehatan Provinsi Sulawesi Tenggara.

4. Dinas Kesehatan Kabupaten Muna Barat. 2019. Profil Kesehatan Kabupaten Muna Barat. Tahun 2016.

5. Puskesmas Wuna, 2019. Laporan Tahunan Puskesmas Wuna. Muna Barat: Puskesmas wuna.

6. Padila, 2013. Buku Ajar Keperawatan Gerontik, Yogyakarta : Nuha Medika.

7. Riskesdas 2018

8. Nasrul, E dan Sofitri. 2012. Hiperurisemia pada Pra Diabetes. Jurnal kesehatan Andalas.

9. Wahyuningsih R. 2013. Penatalaksanaan Diet pada Pasien. Yogyakarta: Graha Ilmu.

10. Utami, P. 2009. Solusi Sehat Asam Urat dan Rematik. Jakarta: Agromedia Pustaka.

11. Andry, S. dan A. S. Upoyo. 2009. Analisis Faktor-faktor yang Mempengaruhi Kadar Asam Urat Pada Pekerja Kantor di Desa Karang Turi, Kecamatan Bumiayu, Kabupaten Brebes. Jurnal Keperawatan Soedirman, 4(1): 26-31

12. Arina, $\mathrm{K}$.2016. Faktor-Faktor yang Berhubungan dengan Kejadian Terduga Hiperurisemia pada Pralansia di Pos Pembinaan Terpadu (Posbindu) Wilayah Kerja Puskesmas Pamulang. Program Studi Kesehatan Masyarakat Fakultas Kedokteran dan IImu Kesehatan Universitas Islam Negeri Syarif Hidayatullah Jakarta.

13. Putri, M.I, 2012. Hubungan aktivitas, jenis kelamin, dan pola diet dengan frekuensi kekambuhan Arthritis Rheumatoid di Puskesmas Nuasa Indah Bengkulu. Diakses 12 Juni 2019.

14. Yenrina, Rina, Diah Krisnatuti, dan Dini Rasjmida. 2014. Diet Sehat Untuk Penderita Asam Urat. Jakarta: Penebar Swadaya.

15. Arina, K 2016. Faktor-Faktor yang Berhubungan dengan Kejadian Terduga Hiperurisemia pada Pralansia di Pos Pembinaan Terpadu (Posbindu) Wilayah Kerja Puskesmas Pamulang. Program Studi Kesehatan Masyarakat Fakultas Kedokteran dan Ilmu Kesehatan Universitas Islam Negeri Syarif Hidayatullah Jakarta.

16. Pursriningsih, S.S. dan B. Panunggal. 2015. Hubungan Asupan Purin, Vitamin C dan Aktivitas Fisik Terhadap Kadar Asam Urat Pada Remaja Laki-Laki. Journal of Nutrition College 4(1): 24-29.
17. Ferllando, H. T., \& Asfawi, S. (2015). Hubungan Antara Sanitasi Lingkungan dan Personal Hygiene Ibu Dengan Kejadian Diare Pada Balita Di Wilayah Kerja Puskesmas Mangkang. VISIKES: Jurnal Kesehatan Masyarakat, 14(2).

18. Hensen, P., \& Tjokorda, R, 2007. Hubungan Konsumsi Purin Dengan Hiperurisemia Pada Suku Bali Di Daerah Pariwisata Pedesaan. Jurnal Penyakit Dalam Indonesia, 8(1), 37-43.

19. Koentjoro, S. L. 2010. Hubungan Antara Indeks Masa Tubuh (IMT) Dengan Derajat Osteoartritis Lutut Menurut Kellgren dan Lawrence. Universitas Diponegoro. Semarang: Artikel Penelitian.

20. Fauzan, A. 2016. Hubungan Indeks Massa Tubuh (IMT), Asupan Purin dan Olahraga dengan Kejadian Gout Athritis Pada Lansia di Wilayah Kerja Puskesmas Tanjung Sari Pacitan. Skripsi.

21. Meliny, Suhadi, Muhamad Sety. 2017. Analisis Faktor Risiko Rematik Usia 45-54 Tahun di Wilayah Kerja Puskesmas Puuwatu Kota Kendari Tahun 2017. JIMKESMAS, 2 (2).

22. Lizawati, L. 2014. Hubungan Indeks Massa Tubuh Dengan Hiperurisemia Pada Usia Dewasa Di Dusun Daleman Gadingharjo Sanden Bantul. Naskah Publikasi.

23. Lim, M.Y. 2007. Crash Course Third Edition: Metabolism and Nutrition. UK: Elsevier 


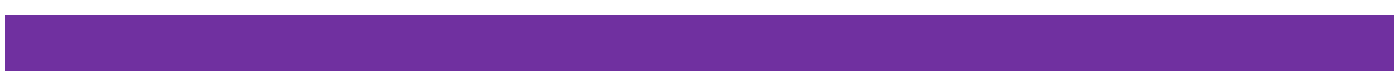

